\title{
The Investigation of the Attitudes of Preservice Teachers Regarding the Rights of the Child
}

\author{
Bilgen Kiral \\ Correspondance: Bilgen Kiral, Aydin Adnan Menderes University, Faculty of Education, Educational Administration \\ Department, Aydin, Turkey.
}

Received: December 16, 2018

Accepted: January 8, 2019 Online Published: January 9, 2019

doi:10.11114/jets.v7i2.3882

URL: https://doi.org/10.11114/jets.v7i2.3882

\begin{abstract}
The research was designed in the descriptive survey model, which is one of the quantitative research methods, with the aim of revealing the attitudes of preservice teachers regarding the rights of the child. The target population of the research was composed of 1419 students studying in the classroom teaching departments in education faculties of seven universities from seven different geographical regions of Turkey in 2017-2018 academic year, which were selected by random sampling. The research was carried out with 818 students who were selected by multiphase sampling and who volunteered to participate in the study. The scale in the research was named "questionnaire for measuring attitudes towards children's rights". The data was collected with this scale. According to the results, it was found that students' attitudes towards children's rights who participated in the research were high. While no significant differences were found according to the students' class levels and taking course regarding child/human rights variables, there were significant differences according to gender and university variables. It was revealed that the attitudes of the female students regarding the rights of the child were higher than those of male students; and the attitudes of the students regarding the rights of the child in Trakya University were higher than those in Adiyaman University. Regarding the results obtained, various suggestions were made such as giving the courses related to the rights of the child within the framework of compulsory courses and increasing the informative education activities for male students regarding the rights of the child.
\end{abstract}

Keywords: child rights, preservice teachers, classroom teaching department

\section{Introduction}

It is known by everybody that human beings have such life stages as infancy, childhood, adolescence, youth, adulthood, and old age. The individual has some rights beginning from the period in the uterus of the mother. These rights begin with the prenatal period and continue in the postnatal stages of life. One of the most important stages of the individual's life is undoubtedly the childhood period. In childhood period, the rights of the individual consider the child as a human and receive a child-specific name. These rights are called as "the rights of the child" and the child benefits from these rights until he or she is 18 years old. As the individual turns the age of 18, this concept is substituted by the concept of "human rights" and its framework is drawn by laws.

Article 28 of the Turkish Civil Code states that "the child receives the capacity to have rights, on the condition that he or she is born alive, the time when he or she is in the uterus of the mother" while Article 1 of the Convention on the Rights of the Child confirms that every individual is a child until the age of 18. In the Article 6 of the Turkish Penal Code, it is stated that the individuals who are under the age of 18 will be considered as children. As can be seen in the legal statements, children are born with having some rights before birth (Kiral, 2018a). Freeman $(1998,2007)$ also states that children have a number of rights to guarantee their personalities, autonomies and lives wherever they are around the world and that they are guaranteed by law.

It can be revealed that various studies have been carried out in order to improve the rights of children and to ensure their survival and protection in good conditions (Freeman, 1998; 2007). For example; "the Geneva Declaration of the Rights of the Child" in 1924 was the first international legal document on the rights of the child in the world. In this document, there are such articles for the child's sake as child's nutrition, medical treatment, protection from abuse, and helping the child in various situations (Freeman, 2000). In this declaration, there are statements such as keeping the child in appropriate conditions to let him or her improve spiritually and physically, feeding the child when hungry, treating the child when sick, prompting the child when falling behind mentally, protecting the child when abandoned, taking 
precautions against all kinds of abuse, helping the child first before in case of any disasters (Inan, 1968). Another important document concerning the Rights of the Child is "the Convention on the Rights of the Child" and it was accepted by the United Nations General Assembly on 20 November 1989 (UNICEF, 2004). The Convention on the Rights of the Child consists of 54 articles and provides regular information on the rights that children should have. These rights can be analyzed in four categories as; the right of the child to live (the right to live, to have appropriate life standards, the right of health, nutrition and housing); the right of the child to develop (the freedom of education, playing, resting, religion, conscience and thought); the right of the child to participate (the right of expressing opinions, establishing associations, meeting, decision making) and the right of the child to be protected (in the court, in armed conflicts, against all kinds of physical-emotional and sexual abuse, and against drug addiction) (Akyuz, 2001). The entry of this convention into force in Turkey was by its publication in the Official Gazette numbered 22184 dated 27.01.1995 (Topsakal and Ayyurek, 2012).

According to Morrow (1999), among the reasons of carrying out various studies on the rights of the child, there are such reasons as the fact that children do not have the political rights to vote or to work for their own benefits. They have neither political rights nor economic rights. Children are disadvantageous in this situation because they are not independent and do not have any rights to act independently. Children are passive as they are under the protection of their parents; they are as if their families' personal, private items. They are open to the abuse, neglection and exploitation of adults. Therefore, they are in need of protection.

By Article 41 of the 1982 Constitution of Turkish Republic stating that "Every child has the right of protection and benefiting from care, unless obviously controversial to his or her high interests, establishing and maintaining personal and direct relationships with his or her parents. The state takes protective measures for the child against all forms of abuse and violence", the life of the child is taken under protection. Therefore, it is necessary to teach children what their rights are because children are the most vulnerable group against such situations as neglection, abuse, harassment or being put on the spot, and suffering under others (O’Neill, 1988). Children should be protected, their rights should be peculiarly determined and they should be taught their rights through families at first and then through teachers beginning from the preschool period.

For this reason, the "Family Education Program", which covers 0-18 years of age, was established and started to be implemented in 2010. These programs aim to provide families with knowledge, skills and attitudes about child care, development and education. Program, classroom teacher, preschool, child development and education, guidance teachers with the "Family Education Practitioner Certificate" is given by educators in formal and non-formal education institutions are implemented. Children's rights are included as a separate module in the content of the programs (Ministry of Education Family Education Program, 2018)

Apart from those mentioned above, the main reason of the studies conducted on the rights of the child is to challenge against the discrimination of children, to put forward the rights of the child, to prevent the crimes against children, to be a pioneer in the moral education of the child, to respect the autonomy and dignity of the child, to ensure that the child is treated appropriately, to ensure that the child is treated differently from the adults in terms of the crimes that the child commits at home, at school, at workplace, in the street etc. in the light of laws and contracts, to improve the children's lives (Freeman, 1998). An education based on the rights of the child, parallel to the life of the child and his or her development is provided by the child's family environment, school environment and the contribution of the society (Uluc, 2008). Therefore, the education of the rights of the child should be started at an early age (Arslan and Ozturk Fidan, 2018).

Elementary school education has a large share in the education of the rights of the child. Basic citizenship competencies and values are introduced to children in this period (Mayall, 2000) because each child has the right to know about the other rights as a child such as being protected, feeling respect, being accepted as an individual within the society, and expressing himself or herself. The rights of the children need to be attached the required significance. The rights of the children should be taken seriously not just by family but also by the school. İn this way, there will be great contributions to make the children acquire a respect culture, character development, citizenship awareness, capacity development and recognition of democracy (Landsdown, Jimerson and Shahroozi, 2014). By taking into account the fact that the rights of all children should be taken seriously, Freeman (1992) emphasizes that every child, without any discrimination, should be given the deserved respect to his or her rights as a child, individual autonomy and thoughts. According to Kiral (2018a), the aim of the studies conducted is to protect children, to teach them their rights, and to make them become a part of the society and become a social entity. İn order to achieve this, various studies are carried out within the family first, and then in the educational institutions.

According to Bennett and Hart (2001), educational institutions are institutions that produce and teach values. Through the education system, students learn to respect other children, their families, the society, human rights and the rights of the child. Education also teaches students the rights of others as well as their own rights, and to respect these rights. By means of appropriate activities for each age beginning from preschool through tertiary education, it is necessary to 
provide education gradually that regulates the relationships of the child with other people and with the society such as democracy, human rights and citizenship education (Alderson, 1999; Patrick, 2003).

In their study, Asiegbor, Fincham, Nanang, Gala and Britwum (2001) revealed that the teachers did not have the adequate knowledge and skills about human rights education. This result could be interpreted as the fact that the teachers did not have enough knowledge about teaching this subject in order to be able to conduct effective human rights education, and that they could not meet this knowledge sufficiently in preservice education. Covell and Howe (1999) stated that the children who received the rights of the child education at school were more knowledgeable about the rights of the child and showed more respect for the rights of others. For this reason, teachers should have knowledge about this subject. Hence, according to the research carried out by Kiral (2018a), the children studying in both the village and the city center expressed that they had learned the rights they had from their teachers. Therefore, teachers are important factors for the students in learning their rights. For this reason, the teachers who will teach the rights of the child should have knowledge about this first. The first place for this is the university where teaching as a profession is formed.

Teachers who will shape the future of the countries and who will teach the children should be given courses about the rights of the child in the preservice period during their years at university; especially when they start working as teachers, this knowledge should be reinforced through in-service training. However, before these trainings are provided, the awareness levels of the teachers should be determined and trainings should be planned accordingly. Baginsky (2000a) pointed out that the rights of the child education should be provided especially by teacher training institutions because it is the teachers who will teach children their rights. Furthermore, the fact that teachers knew and internalized this knowledge before they began teaching could be effective in providing the students the required education. of course, the government also has important responsibilities in this training. It is necessary to teach basic human rights trainings without seeing the child as a commercial vehicle without discriminating between the state and the private school (Bayram, 2018).

When the studies in Turkey on the Rights of the Child (e.g. Karaman Kepenekci, 2006; Karaman Kepenekci and Baydik, 2009; Kaya, 2011) were analyzed, it was concluded that there were no studies including the students studying in education faculties of the universities in Turkey in general. Thus, in this study, it was aimed to determine the attitudes of classroom teaching students regarding the rights of the child. In accordance with this purpose, it was aimed to answer the following questions:

1. What are the attitudes of the students in the classroom teaching department regarding the rights of the child?

2. Do the attitudes of the students in the classroom teaching department regarding the rights of the child show significant differences according to gender, class level, taking course regarding child/human rights, and university variables?

\section{Method}

This study, which aimed to reveal the attitudes of classroom teaching students regarding the rights of the child is a descriptive survey model. The aim in the descriptive survey model is to reveal the current situation related to the topic under investigation (Balci, 2009; Buyukozturk, Cakmak, Akgun, Karadeniz and Demirel, 2008; Karasar, 1991).

\subsection{Population and Sample}

The target population of the research was composed of $1^{\text {st }}$ and $4^{\text {th }}$ grade students studying in classroom teaching department of education faculties at universities in Turkey. In the research, sampling method based on specific procedures was used in sample selection. This method was determined with the aim of comparing the known characteristics of the sample in the population in order to test the representation degree of the sample, which is the condition of providing external validity in the research. In the study, as it was impossible to reach all the students in Turkey, one university from each geographical region in Turkey was selected with random sampling method. After that, the $1^{\text {st }}$ and $4^{\text {th }}$ grade students in education faculties of these universities selected were determined as stratums in accordance with the purpose of the research. These students were selected with the aim of determining whether the attitudes of the students when they began university and their attitudes after they had education, before they graduated from university differed or not. The number of students in these stratums was determined by complete inventory, and by taking into consideration the possible problems to be experienced in the returns (such as lack of volunteer students, wrong filling-ins, scratches, incomplete filling-ins, etc.), a number of questionnaires as much as the number of current students in the department in each university was sent to the instructors who would conduct the application. After the instructors who would conduct the application made the necessary explanations about the data collection tool for the students among the $1^{\text {st }}$ and $4^{\text {th }}$ grade students who had wanted to voluntarily participate in the research, they gave the questionnaires to fill in and collected them from the students afterwards (Balci, 2009; Buyukozturk et al., 2008).

The universities selected randomly within the framework of the research were; Aydin Adnan Menderes University (ADU), Adiyaman University (ADYU), Ankara University (AU), Burdur Mehmet Akif Ersoy University (MAKU), Edirne Trakya 
University (TU), Ordu University (OU) and Van Yuzuncu Yil University (YYU). The number of $1^{\text {st }}$ and $4^{\text {th }}$ grade students at the universities within the framework of the research, the number of the students who participated in the research, and the number and percentage of the data collection tools included in the evaluation were given in Table 1.

Table 1 . The number of $1^{\text {st }}$ and $4^{\text {th }}$ grade students at the universities, the number of the students who participated in the research, and the number and percentage of the data collection tools included in the evaluation

\begin{tabular}{ccccc}
\hline University & $\begin{array}{c}\text { Total number of } \mathbf{~}^{\text {st }} \\
\text { and } \mathbf{4}^{\text {th }} \text { grade } \\
\text { students }\end{array}$ & $\begin{array}{c}\text { students } \\
\text { who participated } \\
\text { in the research }\end{array}$ & $\begin{array}{c}\text { collection tools } \\
\text { included } \\
\text { in the evaluation }\end{array}$ & Percentage $(\%)$ \\
\hline ADU & 202 & 155 & 151 & 18.4 \\
ADYU & 211 & 101 & 100 & 12.2 \\
AU & 191 & 101 & 98 & 12.0 \\
MAKU & 247 & 95 & 94 & 11.5 \\
OU & 113 & 62 & 62 & 7.6 \\
TU & 242 & 199 & 196 & 24 \\
YYU & 213 & 125 & 117 & 14.3 \\
\hline Total & 1419 & 838 & 818 & 100 \\
\hline
\end{tabular}

In Table 1 as could be seen, 59\% of the students (n: 838) in the population (n: 1419) participated in the research. However, during the investigation of the data, 20 data collection tools detected that they were not properly filled in (scratches, incomplete filling-ins, etc.) were not included into evaluation and the research was carried out through 818 (57\%) data collection tools. Of the data collection tools included into evaluation; $18.5 \%$ (n: 151 ) was obtained from Aydin Adnan Menderes University, 12.2\% (n: 100) from Adiyaman University, 12\% (n: 98) from Ankara University, 11.5\% (n: 94) from Burdur Mehmet Akif Ersoy University, $7.6 \%$ (n: 62) from Ordu University, 24\% (n: 196) from Edirne Trakya University, and 14.3\% (n: 117) from Van Yuzuncu Yil University. Table 2 shows the personal information of the students who participated in the research.

Table 2. Descriptive Statistics in Terms of the Students Who Participated in the Research

\begin{tabular}{|c|c|c|c|}
\hline & & $\mathbf{n}$ & $\%$ \\
\hline \multirow{2}{*}{ Gender } & Female & 608 & 74.3 \\
\hline & Male & 210 & 25.7 \\
\hline \multirow{2}{*}{ Class } & $1^{\text {st }}$ grade & 430 & 52.6 \\
\hline & $4^{\text {th }}$ grade & 388 & 47.4 \\
\hline \multirow{2}{*}{ Taking the course } & Yes & 58 & 7.1 \\
\hline & No & 760 & 92.9 \\
\hline & & 818 & 100 \\
\hline
\end{tabular}

According to Table 2, it was found that $74.3 \%$ (n: 608) of the students who participated in the research were female and $25.7 \%$ (n: 210) of them were male; $52.6 \%$ (n: 430 ) of them were $1^{\text {st }}$ grade students and $47.4 \%$ (n: 388 ) were $4^{\text {th }}$ grade students; $7.1 \%$ (n: 58) of them took courses regarding the rights of the child/human rights and $92.9 \%$ (n: 760 ) did not take any related courses.

\subsection{Data Collection Tool}

In the research; the personal information form prepared by the researcher including the questions on the participants' gender, age, class level, and whether they have taken a course on human rights or the rights of the child, and the scale "questionnaire for measuring attitudes towards children's rights" developed by Karaman Kepenekci (2006) was used in order to determine the attitudes of the university students regarding the rights of the child. The one-dimensional, 5-point-Likert (I Totally Agree, I Agree, I am Neutral, I Disagree, and I Totally Disagree) scale consists of 22 items, 19 of which are positive and 3 of which are negative (reverse coded), regarding the children's biological, developmental, protection and participation rights. The answers given to the statements in the scale are scored as 1,2, 3, 4 and 5 points. As the score goes up, it is the indicator that there is an attitude regarding the rights of the child. Since the scale was previously used by many researchers (Aldemir, 2014; Ekici, 2014; Karaman Kepenekci, 2006; Karaman Kepenekci and Baydik, 2009; Leblebici and Celikoz, 2017) in the studies on the students studying at education faculties, the construct validity was not tested again. In the first study by Karaman Kepenekci (2006), the Cronbach Alpha internal consistency coefficient of the scale was found .85. Within the framework of this research, the Cronbach Alpha internal consistency coefficient of the scale was found .80 .

\subsection{Data Analysis}

In analyzing the data; frequency, percentage, mean, and parametric difference tests appropriate to the characteristics of 
the data were used. The attitudes of the students regarding the rights of the child were analyzed with mean scores and standard deviation; and whether their attitudes regarding the rights of the child showed significant differences according to university, gender, class and taking the course was analyzed with parametric difference tests (t test and ANOVA). In order to determine whether the data met the normality conditions, the measures of central tendency (mean, median and mode values), and skewness and kurtosis coefficient values were investigated. The fact that the measures of central tendency were close to one another and that the skewness and kurtosis coefficient values were between +1.5 and -1.5 (Tabachnick and Fidell, 2013) were evaluated that the data showed normal distribution. The significance of the statistics obtained was tested bidirectionally at .05 level.

\section{Findings}

The data obtained within the scope of the research were, in line with the aim of the research, summarized below as the findings in terms of the rights of the child and the findings in terms of the investigation of the rights of the child according to various variables.

3.1 The Findings in Terms of the Attitudes Regarding the Rights of the Child and in Terms of the Investigation of the Rights of the Child According to Various Variables

As a result of the analysis of the data, it was found that the mean score ( $\overline{\mathrm{X}}: 4.74$, sd: .26) of the attitudes of the university students regarding the rights of the child (n: 818) was relatively high. The results of the analysis on whether the attitude scores of the students regarding the rights of the child differed according to class level, gender and taking the course variables were given in Table 3 .

Table 3. t Test Results Regarding Class Level, Gender, and Taking the Course

\begin{tabular}{|c|c|c|c|c|c|c|c|}
\hline Variables & & n (818) & $\overline{\mathbf{X}}$ & sd & df & $\mathbf{t}$ & p \\
\hline \multirow[t]{2}{*}{ Class Level } & $1^{\text {st }}$ grade & 430 & 4.72 & .25 & & 1.523 & .128 \\
\hline & $4^{\text {th }}$ grade & 388 & 4.75 & .26 & & & \\
\hline \multirow[t]{2}{*}{ Gender } & Female & 608 & 4.76 & .24 & 816 & 4.761 & $.000^{*}$ \\
\hline & Male & 210 & 4.66 & .30 & & & \\
\hline \multirow[t]{2}{*}{ Taking the Course } & Yes & 58 & 4.71 & .24 & & .857 & .392 \\
\hline & No & 760 & 4.74 & .26 & & & \\
\hline
\end{tabular}

As could be seen in Table 3, it was found that there was no significant difference between the attitude scores of the $1^{\text {st }}$ grade students regarding the rights of the child ( $\overline{\mathrm{X}}: 4.72$, sd: .25$)$ and the attitude scores of the $4^{\text {th }}$ grade students $(\overline{\mathrm{X}}$ : 4.75, sd: .26) [ $\left.\mathrm{t}_{(816)}: 1.523 ; \mathrm{p}>.05\right]$. Similarly, it was revealed that there was no significant difference between the attitude scores of the students taking the course regarding the rights of the child/human rights $(\overline{\mathrm{X}}: 4.71, \mathrm{sd}: .24)$ and the attitude scores of those not taking the course regarding the rights of the child/human rights $\left(\overline{\mathrm{X}}: 4.74\right.$, sd: .26) [t $\mathrm{t}_{(816)}$ : .857; $\mathrm{p}>.05]$. However, it was found that the attitudes of female students regarding the rights of the child ( $\overline{\mathrm{X}}: 4.76$, sd: .24$)$ were significantly higher than the attitudes of male students regarding the rights of the child $(\overline{\mathrm{X}}: 4.66, \mathrm{sd}: .30)\left[\mathrm{t}_{(816)}\right.$ : $4.761 ; p>.05]$. When the effect size of the mentioned difference was examined, it was determined that this effect was at moderate level $(\mathrm{d}=.38)$ (Cohen, 1988).

The findings obtained from the analysis performed on whether the attitude scores of the students regarding the rights of the child differed according to university variable were given in Table 4.

Table 4. ANOVA Analysis Results Regarding the University Variable

\begin{tabular}{|c|c|c|c|c|c|c|c|}
\hline University & $\mathbf{n}$ & $\overline{\mathbf{X}}$ & sd & df & $\mathbf{F}$ & $\mathbf{P}$ & Sig. Dif. \\
\hline 1- ADYU & 100 & 4.66 & .25 & & & & \\
\hline 2- ADU & 151 & 4.75 & .24 & & & & \\
\hline 3-AU & 98 & 4.69 & .29 & & & & \\
\hline 4- MAKU & 94 & 4.73 & .23 & $6 ; 811$ & 3.349 & $.003^{*}$ & $1-6$ \\
\hline 5- OU & 62 & 4.76 & .27 & & & & \\
\hline 6- TU & 196 & 4.78 & .25 & & & & \\
\hline 7- YYU & 117 & 4.74 & .26 & & & & \\
\hline
\end{tabular}

When Table 4 was examined, it was seen that there was a significant difference between the attitude scores of the students regarding the rights of the child according to university variable $\left[\mathrm{F}_{(6,811)}: 3.349, \mathrm{p}<.05\right]$. İ order to determine between which universities this statistically significant difference was, Tukey multiple comparison test was used. As a result of the test conducted, it was found that the attitude scores of the students studying at Trakya University regarding the rights of the child ( $\overline{\mathrm{X}}: 4.78$; sd: .25) were relatively higher than the attitude scores of the students studying in Adiyaman University $(\overline{\mathrm{X}}: 4.66$; sd: .25$)$. The measured eta squared effect size $\left(\eta^{2}=.02\right)$ as a result of the test result exhibited that this difference was little (Green and Salking, 2005). 


\section{Conclusion, Discussion and Suggestions}

The aim of this study was to investigate the attitudes of the classroom teaching department students regarding the rights of the child and their relationships with various variables. It was found that the students' attitudes regarding the rights of the child were relatively high. It could be said that the students had a positive attitude regarding the rights of the child. Similarly, in the researches by Ekici (2014), Karaman Kepenekci and Baydik (2009), Leblebici and Celikoz (2017), it was found that the attitudes of the students regarding the rights of the child were high. The efforts to increase awareness on this subject in the social media might be stated among the reasons why the attitudes of the students were found to be high.

It was found that there was no significant difference between the attitudes of $1^{\text {st }}$ grade students and the attitudes of $4^{\text {th }}$ grade students regarding the rights of the child. Besides, it was revealed that there was no significant difference between the attitude scores of the students taking a course regarding the rights of the child/human rights and the attitude scores of those not taking a course regarding the rights of the child/human rights. There are some studies suggesting that taking courses on human rights or the rights of the child positively affects the attitudes regarding the rights of the child. Covell and Howe (1999) found in their research that informing about the rights of the child positively affected the attitudes regarding the rights of the child. The finding obtained in the study by Karaman Kepenekci (2006) revealing that the attitudes of the students taking a course regarding the rights of the child/human rights are more positive than the attitudes of the students not taking a course regarding the rights of the child/human rights supports this situation. In the study carried out by Karaman Kepenekci and Baydik (2009), it was found that the views of the students taking a course regarding the rights of the child/human rights were relatively higher than those who did not take any related courses. İn the research by Nesliturk and Ersoy (2007) conducted on preschool education students, it was revealed that the students did not have enough knowledge about teaching the rights of the child. Furthermore, all the students participating in the research stated that teaching the rights of the child should be included in the preschool period due to such reasons as contributing to behavior development, becoming individuals who are aware of their rights, being able to defend themselves and developing empathy.

Patrick (2003) stated that democracy education should be gradually given through activities appropriate for all ages from preschool to higher education. Within the scope of democracy education, human rights education should also be included. For this reason, teaching the rights of the child should be included beginning from the preschool period and this education should also be involved in the teacher training departments of the universities. Covell and Howe (1999) also emphasized the importance of the education regarding the rights of the child and expressed that the education on the rights of the child and human rights was necessary in order to promote the respect, attitudes and behaviors in all individuals. Asiegbor et al. (2001) stated that teachers should have sufficient knowledge about teaching such basic knowledge as the rights of the child and human rights so that they could perform effective human rights education. However, there are also researches revealing that teachers do not have enough knowledge. In the research by Kor (2013), it was found that most of the teachers did not receive any education on the rights of the child before. It was emphasized that the majority of the teachers had general knowledge known by everybody regarding "the right of the child to live and develop, giving priority to the high benefits of the child, taking into consideration the views of the child and the right of the child to participate. In the study by Kaya (2011) on the students studying in the $3^{\text {rd }}$ and $4^{\text {th }}$ grades, it was revealed that the majority of the students did not read the convention on the rights of the child and that they did not have sufficient knowledge on this subject. In a system where the individuals between 0 and 18 years of age are considered as children, it is thoughtful that teacher training institutions do not provide courses on the rights of the child. It is very important for the individuals whose duty is to give education to children to receive this education and read the convention on the rights of the child in terms of positively affecting their attitudes towards children.

According to gender variable, it was found that the attitudes of female students regarding the rights of the child were higher than the attitudes of male students regarding the rights of the child. This might be due to the fact that female students did not want to experience the unwanted behaviors and attitudes they were exposed to during their stages of growth in the future and that they raised their awareness by reading the necessary information. And also sense of motherhood effects the attitudes for female students. Furthermore, in the study by Leblebici and Celikoz (2017) on preschool education and classroom teaching students, similar to the results of the present study, it was found that female students had higher attitudes regarding the rights of the child compared to male students. However, various studies (Karaman Kepenekci, 2006; Karaman Kepenekci and Baydik, 2009) revealed that there was no significant difference between the views of male and female students.

According to university variable, the attitudes of the students regarding the rights of the child did not show any significant differences except for Trakya University and Adiyaman University. The attitudes of the students studying at Trakya University regarding the rights of the child were found to be higher than the attitudes of the students studying at Adiyaman University regarding the rights of the child. On the one hand, the students in Trakya University are having their university education in the west part of Turkey where the people are more extroverted in their relationships, where they behave more comfortably, are aware of their rights as individuals and are able to exhibit them in their lives. On the 
other hand, the students at Adiyaman University are having their education at a university in the south east region of the country where, due to the location and life conditions, child workers are widespread and child labor is mostly exhibited. It can be said that the students having their education at this university might have indigenized this situation by witnessing it and accepted it as if it was something normal. Kagizmanli, Kaya, Ozguler and Altug's research of students receiving higher education in the west Turkey that perspective, it has been found to be different from the east.

When education systems are formed, they should be based respect for not only children but also their families and other people living within the society, and should be shaped accordingly (Bennett and Hart, 2001). Respect is a value that affects groups, institutions and countries, and it is not just interpersonal (Kiral, 2018b). Since respect is a value that is shaped by the whole of the notions and behaviors showing that the individual is important and valued (Calisici Celik and Kiral, 2018), the consciousness of respect in education should begin with the child at an early age. The respect that is shown and taught to the child today is reflected in his or her present and future life. In order to have a healthy and happy society, the rights of the child should be protected beginning from today and the education regarding the rights of the child should be paid the necessary attention at schools. The institutions training teachers should also take this into account and this education should be given the required attention both formally and informally. If the children know their rights, they learn to respect each other.

In their study, Kiral and Basdag (2017) stated that such values as if love, respect, honesty, tolerance and mercy should be given in the family and reinforced in the school by the teacher. Akyuz (2001) expressed that the individuals who spend their childhood happily and healthily live as happy and healthy citizens in adulthood and contribute to the welfare of the society. Baginsky (2000b) stated that especially the professionals who are interested in the education of the rights of the child should be prepared and educated accordingly. İn the studies by the researches such as Casas et al. (2006), Kor (2013), and Shumba (2003) etc., it was concluded that the trainers were not educated or did not have sufficient knowledge regarding the rights of the child. In the study conducted by Hodgkinson and Baginsky (2000), it was found that school-centered teacher training courses based on the rights of the child were effective. It could be said that education on the rights of the child might be beneficial not only for the child but also for the future of the country.

Osler and Starkey (1998) pointed out the important role of schools in teaching the children the rights of the child. Such enlightenment should be provided as part of the school program. Furthermore, the school should be introduced to society as an environment in which the respect to human rights is exhibited. For this reason, the Convention on the Rights of the Child should be known firstly by the educators. It can be said that if the content of the convention is known by all the stakeholders of the school, initially by the teachers, a school climate away from violence in which democratic attitudes are exhibited will be dominant (Hammarberg, 1990). After all, it is stated in the article 42 of the Convention on the Rights of the Child that "State Parties ensure that the principles and provisions of the Convention are learned by children as well as adults by means of appropriate and effective tools. In short, it is emphasized in this article that everyone should learn the rights of the child.

The education regarding the rights of the child should be received beginning from preschool through graduation from university. The fact that an individual who will perform teaching as his or her work receives the education regarding the rights of the child is the right of the students to be educated in the future. Learning these is also the greatest responsibility of a teacher. The education of all individuals regarding the rights of the child should be taken into consideration through the in-service trainings, seminars, conferences and symposiums to preservice teachers, in undergraduate education period, and to the teachers in service. The most important period of the childhood takes place at primary schools and under the supervision of classroom teachers. The full knowledge of classroom teachers regarding the rights of the child can be important in terms of their approaches towards children. The necessary support regarding the rights of the child can be given to the teachers who are currently working by means of providing various trainings and carrying out related studies by the universities, media and the Ministry of National Education.

The attitudes of the preservice teachers regarding the rights of the child were found to be high in this research and thus, workshops organized by the students in universities can be carried out to protect and improve this situation. As the attitudes of male students were found to be low according to the results of this research conducted in order to determine whether the students studying in the classroom teaching departments of education faculties were aware of the rights of the child and to reveal their attitudes. Educations peculiar to male students can be given and the courses at all the universities regarding the rights of the child and human rights (considering the fact that every individual is child until the age of 18) can be taken out of elective courses in all departments and included in compulsory courses. Studies directed to male students can be increased and the awareness levels of male students can be enhanced by giving tasks to them in the social responsibility projects related to the rights of the child. Furthermore, by using qualitative research methods, the things that should be done regarding the rights of the child can be investigated. A similar research can be carried out with the university students, the teachers who are at the beginning of their professions, those who are experienced in their professions, and those who are going to retire in the near future and the results can be compared. 


\section{References}

Akyuz, E. (2001). Child Law. Ankara: Pegem Akademi.

Aldemir, E. (2014). Nursing students' attitudes concerning the determination of children's rights. Master Thesis. İstanbul Bilim University, İstanbul.

Alderson, P. (1999). Human rights and democracy in schools do they mean more than"picking up litter and not killing whales"? The International Journal of Children's Rights, 7, 185-205. https://doi.org/10.1163/15718189920494336

Arslan, P. \& Ozturk Fidan, I. (2018). Evaluation of current status the rights of children in Turkey. Professor Dr. Emine Akyuz is the gift: 50 years in academician. (p. 253-264). In Y. Karaman Kepenekci \& P. Taskin (Eds.). Ankara: Pegem Academy.

Asibegbor, İ., Fincham, K., Nanang, M., Gala, E. E. K., \& Britwum, A. O. (2001). Rights and equity in the classroom: A case study of classroom interactions in basic schools in Ghana. http://www.unicef.org/evaldatabase/files/gha_01-006.pdf. Erisim Tarihi: 13.11.2018.

Baginsky, M. (2000a). Training Teachers in Child Protection. Child Abuse Review, 9, 74-81. https://doi.org/10.1002/(SICI)1099-0852(200001/02)9:1<74::AID-CAR578>3.0.CO;2-2

Baginsky, M. (2000b).Child Protection and Education. London: NSPCC.

Balci, A. (2009). Research in Social Sciences. Ankara: Pegem A.

Bayram, A. (2018). The reflection of neoliberal economic policies on education: Privatization of education in Turkey. European Journal of Educational Research, 7(2), 341-347.

Bennett, J., \& Hart, S. N. (2001). Respectful learning communities, Laying the foundations of human rights, democracy and peace in the new millennium. in S. N. Hart, C. P. Cohen, M. F. Erickson, \& M. G. Flekkoy (Eds). Children's Rights in Education. London: JessicaKingsley.

Buyukozturk, S., Cakmak, E. K., Akgun, O. A., Karadeniz, S., \& Demirel, F. (2008). Scientific Research Methods. Ankara: Pegem Akademi.

Calisici, C. N., \& Kiral, B. (2018). Administrator and teacher opinions regarding the respect of the teaching profession. Turkish Studies, 13(27), 405-432.

Casas, F., Sapariti, A., González, M., Figuer, C., Rostan, C., Sadurni, M., ... Rago, M. (2006). Children’s rights from the point of view of children, their parents and their teachers: A comparative study between Catalonia (Spain) and İ Molise (İtaly). The International Journal of Children's Rights, 14, 1-75.

https://doi.org/10.1163/157181806776614336

Cohen, J. (1988). Statistical power analysis for the behavioral sciences (2nd ed.). Hillsdale, NJ: Erlbaum.

Covell, K., \& Howe, R. B. (1999). The impact of children's rights education: A Canadian study. International Journal of Children's Rights, 7(2), 171-183.

Ekici, F. Y. (2014). Examining prospective teachers' attitudes towards child rights in terms of some variables. The Journal of Academic Social Science, 8, 66-77.

Freeman, M. (1992). Taking children's rights more seriously. International Journal of Law and the Family, 6, 52-71. https://doi.org/10.1093/lawfam/6.1.52

Freeman, M. (1998). The sociology of childhood and children's rights. The International Journal of Children's Rights, 6 , 433-444. https://doi.org/10.1163/15718189820494175

Freeman, M. (2000). The Future of Children's Rights. Children \& Society, 14, 277-293. https://doi.org/10.1111/j.1099-0860.2000.tb00183.x

Freeman, M. (2007). Why it remains important to take children's rights seriously. International Journal of Children's Rights, 15, 5-23. https://doi.org/10.1163/092755607X181711

Hammarberg, T. (1990). The UN Convention on the Rights of the Child--And How to Make İt Work. Human Rights Quarterly, 12(1), 97-105. https://doi.org/10.2307/762167

Hodgkinson, K., \& Baginsky, M. (2000). Child Protection Training in School Based İnitial Teacher Training: A survey of school-centred initial teacher training courses and their trainees. Educational Studies, 26(3), 269-279. https://doi.org/10.1080/03055690050137105

Inan, A. N. (1968). Child Law. Ankara: Ankara University Education Faculty Pub.

Karaman, K., \& Baydik, B. (2009). Attitudes of the teacher candidates of mentally handicapped children about 
children's rights. Ankara University Journal of Educational Sciences, 42(1), 329-350. https://doi.org/10.1501/Egifak_0000001150

Karaman, K.Y. (2006). A Study of university students' attitudes towards children's rights in Turkey. The International Journal of Children's Rights, 14, 307-319. https://doi.org/10.1163/157181806778458095

Karasar, N. (1991). Scientific Research Method. Ankara: Nobel.

Kaya, A. O. (2011). Views of teacher candidates on child rights. Master Thesis. Afyon Kocatepe University, Afyon.

Kiral, B. (2018a). Opinions of students in village and city schools about their rights and the violation of their rights. (p. 147-159). Prof. Dr. Emine Akyuz is the Gift: 50 years in academician. Y. Karaman Kepenekci \& P. Taskin (Edts). Ankara: Pegem Akademi.

Kiral, B., \& Basdag, S. (2017). Classroom Teachers' Opinions about Compassion Education. Trakya Universitesi Journal of Education Faculty, 8(1), 80-97.

Kiral, E. (2018b). Vanished Value: Respect. Journal of Contemporary Administrative Science, 5(1), 4-9.

Kor, K. (2013). Determine the pre-school teachers views on children's rights. Master Thesis. Canakkale Onsekiz Mart University, Canakkale.

Landsdown, G., Jimerson, S. R., \& Shahroozi, R. (2014). Children's rights and school psychology: Children's right to participation. Journal of School Psychology, 52, 3-12. https://doi.org/10.1016/j.jsp.2013.12.006

Leblebici, H., \& Celikoz, N. (2017). Prospective teachers' attitudes towards children rights. International Journal of Social Sciences and Education Research, 3(1), 307-318. https://doi.org/10.24289/ijsser.270584

Mayall, B. (2000). The sociology of childhood in relation to children's rights. The International Journal of Children's Rights, 8, 243-259. https://doi.org/10.1163/15718180020494640

Ministry of Education Family Education Program. (2018). http://aileegitimi.meb.gov.tr/ retrived date: 25.11.2018

Morrow, V. (1999). We are people too: Children's and young people's perspectives on children's rights and decision-making in England. The International Journal of Children's Rights, 7, 149-170. https://doi.org/10.1163/15718189920494318

Nesliturk, S., \& Ersoy, A. F. (2007). Preschool teacher candidates' opinions on the teaching of children's rights. Journal of Theory and Practice in Education, 3(2), 245-257.

O’Neill, O. (1988). Children's rights and children's lives. Ethics, 98(3), 445-463. https://doi.org/10.1086/292964

Osler, A., \& Starkey, H. (1998). Children's rights and citizenship: Some implications for the management of schools. The International Journal of Children's rights, 6, 313-333. https://doi.org/10.1163/15718189820494085

Patrick, J. J. (2003). A global perspective on human rights education. (ED: 421447). http://www.eric. gov/ Erisim Tarihi:12.11.2018.

Shumba, A. (2003). Children's rights in schools: What do teachers know? Child Abuse Review, 12, 251-260. https://doi.org/10.1002/car.800

Tabachnick, B. G., \& Fidell, L. S. (2013). Using Multivariate Statistics (6th ed.).Boston: Pearson.

The Constitution of Turkish Republic. (1982). The Official Gazette numbered/dated: 18.10.1982 / 17863.

The Turkish Civil Code. (2001). The Official Gazette numbered/dated: 08.12.2001/24607.

The Turkish Penalty Code. (2004). The Official Gazette numbered/dated: 12.10.2004 / 25611.

Topsakal, C., \& Ayyurek, O. (2012). As seen by teachers: A research focused on students' awareness in the exercise of children's rights. Adnan Menderes University Journal of Education Sciences, 3(2), 37-53.

Uluc, F. O. (2008). Child rights in primary education curricula. Doctoral Dissertation. Ankara University, Ankara.

UNICEF. (2004). The Convention on the Rights of the Child. https://www.unicefturk.org/public/uploads/files/UNICEF_CocukHaklarinaDairSozles me.pdf

\section{Copyrights}

Copyright for this article is retained by the author(s), with first publication rights granted to the journal.

This is an open-access article distributed under the terms and conditions of the Creative Commons Attribution license which permits unrestricted use, distribution, and reproduction in any medium, provided the original work is properly cited. 